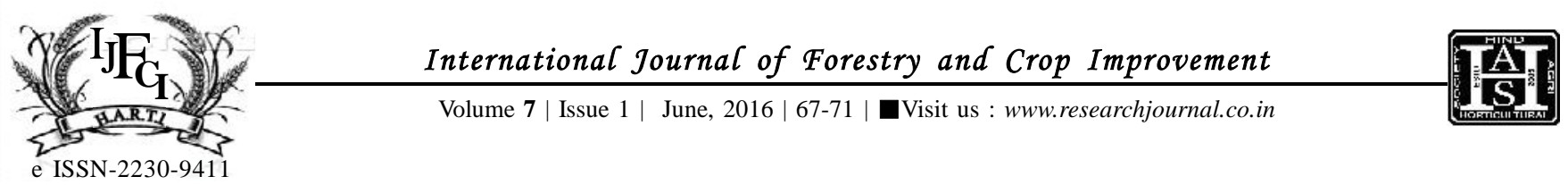

\title{
Influence of organic manures, micronutrients and arbuscular mycoriza on quality parameters of (maize and sunflower) under residual effect of maize- sunflower cropping system
}

\author{
G. Mariappan, M. Mohamed Amanullah, T. Ananthi and M. DHananivetha
}

\begin{abstract}
Field experiments were conducted to study the influence of organic manures, micronutrients and arbuscular mycorrhiza (AM) on the productivity of maize-sunflower cropping system at Tamil Nadu Agricultural University, Coimbatore during 2011-12 and 2012-13. The experiment was laid out in Split Plot Design and replicated thrice for maize during winter 2011-12 and 2012-13 and the same experiment after dividing each plot into two was laid out in Split-split Plot Design with three replications for sunflower during summer 2012 and 2013 to estimate the residual effects of organic manures in maize, the results revealed that among the organic manures, poultry manure @ $5 \mathrm{t} \mathrm{ha}^{-1}$ with RDF recorded significantly enhanced quality parameter like crude protein and starch content in maize followed by application of sericulture waste @ $5 \mathrm{t} \mathrm{ha}^{-1}$ with RDF. Among the micronutrients and $\mathrm{AM}, \mathrm{ZnSO}_{4} @ 37.5 \mathrm{~kg} \mathrm{ha}^{-1}$ recorded significantly crude protein and starch content followed by application of followed by TNAU MN mixture. In sunflower, better oil yield and oil quality were recorded with application poultry manure @ $5 \mathrm{tha}^{-1}$ with RDF to preceding maize followed by sericulture waste @ $5 \mathrm{t} \mathrm{ha}^{-1}$ with RDF to preceding maize. The same trend was also noticed in the second year crop.
\end{abstract}

KEY WORDS : Organic manures, Micronutrients, AM, Maize, Sunflower, Crude protein, Starch, Oil quality

How TO CITE THIS ARTICLE : Mariappan, G., Amanullah, M. Mohamed, Ananthi, T. and Dhananivetha, M. (2016). Influence of organic manures, micronutrients and arbuscular mycoriza on quality parameters of (maize and sunflower) under residual effect of maize- sunflower cropping system. Internat. J. Forestry \& Crop Improv., 7 (1) : 67-71, DOI: 10.15740/HAS/IJFCI/7.1/67-71.

ArTiCle Chronical : Received : 02.02.2016; Revised : 17.04.2016; Accepted : 19.05.2016

MEMBERS OF RESEARCH FORUM

Address of the Correspondence : G. MARIAPPAN, Department of Agriculture

(S.S.\&L.U.O.) VELLORE (T. N.) INDIA Email: gmagri10@ gmail.com

Address of the Coopted Authors : M. MOHAMED AMANULLAH, Department of

Agronomy, Tamil Nadu Agricultural University, COIMBATORE (T.N.) INDIA

T. ANANTHI, Department of e-Extension Center, Tamil Nadu Agricultural University, COIMBATORE (T.N.) INDIA

M. DHANANIVETHA, Department of Agronomy, Tamil Nadu Agricultural University, MADURAI (T.N.) INDIA 